\title{
FISSION TRACK STUDIES ON HORNBLENDE, BIOTITE AND PHLOGOPITE FROM SWEDEN.
}

\author{
Eric Welin, Ingmar Lundström and Göran Aberg
}

Eric Welin, Ingmar Lundström and Göran Åmerg 1972: Fission track
studies on hornblende, biotite and phlogopite from Sweden. Bull. Geol. Soc.

Finland 44, 35-46.

Fission track studies and $\mathrm{K}-\mathrm{Ar}$ dating on three silicate minerals from Sweden have given the following results:

\begin{tabular}{|c|c|c|c|c|c|}
\hline \multirow{2}{*}{ RM 07249 hornblende, Malmberget, } & & \multicolumn{2}{|c|}{ Fission track age } & \multicolumn{2}{|c|}{$\mathrm{K}-\mathrm{Ar}$ age } \\
\hline & Fragment & 11255 & m.y. & 1875 & m.y. \\
\hline \multirow{4}{*}{ RM 620569 biotite, Ingelsbo } & $»$ & 450 & $»$ & & \\
\hline & Fragment & 305 & $»$ & 975 & $»$ \\
\hline & $m 2$ & 520 & $»$ & & \\
\hline & $»$ & 355 & $»$ & & \\
\hline \multirow{3}{*}{ RM 640448-640451 phlogopite,Alnön } & $»$ & 410 & $"$ & & \\
\hline & ,Fragment 1 & 230 & $»$ & 555 & $»$ \\
\hline & $» \quad 2$ & 240 & $»$ & & \\
\hline
\end{tabular}

It is concluded from this investigation that due to inhomogeneous uranium distribution, recent uranium movement and sensitivity for annealing, the fission track dating technique is suitable only for the study of the last thermal event in areas which have undergone a complex geological evolution.

Eric Welin and Göran Aberg, Swedish Museum of Natural History, S-10405 Stockbolm 50.

Ingmar Lundström, Geological Survey of Sweden, S-10405 Stockholm 50.

\section{Introduction}

Charged heavy particles, such as fission fragments, cause serious damages for distances on the order of $10 \mu \mathrm{m}$ when they traverse a crystal lattice. In 1962, Price and Walker (1962 a and $1962 \mathrm{~b})$ made these tracks visible under an ordinary light microscope by etching the surface to be studied with suitable etchants. The etchant preferentially dissolves the damaged material. As a result, fine holes are formed along the particle path. Price and Walker (1963 b) discussed the possible sources of tracks in minerals and concluded that spontaneous fission of $\mathrm{U}^{238}$ most likely has produced all the tracks left by charged particles in minerals. In the same paper Price 
and Walker also showed that the number of tracks produced in a sample by spontaneous fission of $\mathrm{U}^{238}$ is a measure of its age.

Fission tracks in minerals may be recognized by the following criteria (Fleischer and Price 1964): 1. The tracks form line defects. 2. They are straight, randomly oriented and of limited length. 3. They can be made to dissappear by suitable heating.

Provided that the track density can be properly counted on a unit area on the basis of the above criteria, the age of the mineral can be calculated. However, the following conditions must also be fullfilled: 1 . The uranium concentration and the isotope ratio of uranium must not have changed significantly since the crystallization of the mineral. 2. All fission tracks must be retained.

The number of spontaneous fission tracks $\varrho_{\mathrm{s}}$ on a square centrimetre can be calculated according to the following equation (Price and Walker 1963 b):

(1)

$$
\varrho_{\mathrm{s}}=2\left(\lambda_{\mathrm{F}} / \lambda_{\alpha}\right) \mathrm{N}_{\mathrm{o}} \mathrm{C}_{\mathrm{t}} \mathrm{I}_{\mathrm{U}^{238}}\left[\mathrm{e}^{\lambda_{a}{ }^{\mathrm{t}}}-1\right] \int_{\mathrm{o}}^{\mathrm{R}_{\mathrm{o}}} \mathrm{q}(\mathrm{z}) \mathrm{d} \mathrm{z}
$$

where

$\lambda_{\mathrm{F}} \quad=$ decay constant of spontaneous fission of $\mathrm{U}^{238}=8.42 \cdot 10^{-17} \mathrm{yr}^{-1}$

$\lambda_{a}=$ decay constant of $\mathrm{U}^{238}=1.54$. $10^{-10} \mathrm{yr}^{-1}$

$\mathrm{N}_{\mathrm{o}}=$ number of $\mathrm{U}$ atoms per $\mathrm{cm}^{3}$

$\mathrm{C}_{\mathrm{t}}=$ concentration of $\mathrm{U}$ at time $\mathrm{t}$

$\mathrm{t}=$ time since the sample crystallized

$\mathrm{I}_{\mathrm{U}^{238}}=$ isotopic abundance of $\mathrm{U}^{238}=99.273$ at. $\%$

$\mathrm{R}_{\mathrm{o}} \quad=$ range of fission fragments

$\mathrm{q}(\mathrm{z})=$ fraction of the total number of fission events, in a thin slab dz, which traverse the cleavage surface.

$\mathrm{dz}=$ thickness of a thin slab at a vertical distance $z$ from the cleavage surface.
From eq. (1) it is possible to calculate the age of the sample if the $U$ concentration is known and the term $\int_{0}^{{ }^{R}}{ }_{o} q(z) d z$ can be evaluated. The $U$ concentration is, however, in silicate minerals too low to be determined by ordinary analytical methods. Price and Walker (1963 a) have developed a method which is closely related to the spontaneous fission track dating described above. If the sample is exposed to a flux of thermal neutrons, fission is induced in $\mathrm{U}^{235}$ atoms and the track density $\varrho_{\mathrm{i}}$ is expressed by

(2)

$$
\varrho_{\mathrm{i}}=2 \mathrm{~N}_{\mathrm{o}} \mathrm{C}_{\mathrm{t}} \mathrm{I}_{\mathrm{U}^{235}} \mathrm{n}_{\mathrm{t}} \delta \int_{\mathrm{o}}^{\mathrm{R}_{\mathrm{o}}} \mathrm{q}(\mathrm{z}) \mathrm{d} z
$$

where

$\varrho_{\mathrm{i}} \quad=$ induced fission track density per square centimetre

$\mathrm{I}_{\mathrm{U}^{235}}=$ isotopic abundance of $\mathrm{U}^{235}=0.727$ at. $\%$

$\mathrm{n}_{\mathrm{t}}=$ thermal neutron dose per $\mathrm{cm}^{2}$

$\delta=$ cross section for fission of $\mathrm{U}^{235}$ by thermal neutrons $=582 \cdot 10^{-24} \mathrm{~cm}^{2}$.

Thus the concentration of $\mathrm{U}^{235}$ is proportional to the density of induced fission tracks and inversely proportional to the neutron dose:

$$
\mathrm{C}=\text { const } \varrho_{\mathrm{i}} / \mathrm{n}_{\mathrm{t}}
$$

The induced fission tracks are made visible in the same way as described above for spontaneous fission tracks. From the eq. (1) and (2) it is possible to calculate the ratio of spontaneous to induced fission tracks per unit area:

$$
\frac{\varrho_{\mathrm{s}}}{\varrho_{\mathrm{i}}}=\frac{\left(\lambda_{\mathrm{F}} / \lambda_{\alpha}\right) \mathrm{I}_{\mathrm{U}^{238}}\left[\mathrm{e}^{\lambda_{\alpha}{ }^{t}}-1\right]}{\mathrm{I}_{\mathrm{U}^{235}{ }_{\mathrm{t}}} \mathrm{n} \delta}
$$

in eq. (4) the evaluation of the integral $\int_{0}^{R_{o}} q(z)$ is avoided and the concentration of uranium does not enter explicitly. Eq. (4) can be solved for the age $\mathrm{t}$ of the sample. 
(5)

$$
\mathrm{t}=\frac{1}{\lambda_{\alpha}} \ln \left[\varrho_{\mathrm{s}} / \varrho_{\mathrm{i}} \mathrm{n}_{\mathrm{t}} \delta \frac{\lambda_{\alpha}}{\lambda_{\mathrm{F}}} \frac{\mathrm{I}_{\mathrm{U}^{235}}}{\mathrm{I}_{\mathrm{U}} 238}+1\right]
$$

If the surface to be etched was not an interior surface during irradiation, $\varrho_{s} / \varrho_{\mathrm{i}}$ in the above equation has to be multiplied by a factor which is $0.5-0.8$, depending on the investigated material (Reimer et al., 1970). In the double etching technique used in this work (Bigazzi 1967, Berzina and Demidova 1966) an external surface is studied.

\section{Techniques}

\section{Specimen preparation}

In a study of fission tracks in minerals transparent specimens with natural cleavages are the most suitable. Transparent specimens are preferred because the tracks can be studied both in transmitted and in reflected light (Fleischer and Price 1964). Natural cleavages are superior to polished surfaces because they contain no polish scars that can otherwise produce disturbing background effects. In the present study sections of mica were prepared by cleaving mineral fragments to transparent thickness with a razor blade or by stripping off thin leaves with adhesive tape. The first method was preferred. However, some difficulties were encountered in producing large samples with a constant thickness. For this reason, thick, opaque specimens have also been used on occasion.

The transparent samples were then mounted on a glass plate with a layer of Araldite plastic, thick enough to keep the mica out of the range of possible induced fission products from the glass.

Amphibole sections of sufficient size cannot be prepared to transparent thickness simply by cleaving. In order to retain the cleavage surface unaffected the grinding to transparency was performed from the opposite side. The cleavage surface was provisionally cemented to a glass plate with Lakeside $70 \mathrm{C}$ cement. When the section had been ground thin enough the ground side was mounted with Araldite to another plate in the same way as the micas. The Lakeside mounted plate was removed by warming. Finally, any Lakeside cement still present on the cleavage surface was removed by boiling in a $5 \%$ borax solution for about ten minutes.

The prepared sections of mica and amphibole were a half to one square $\mathrm{cm}$ in size.

\section{Etching}

The etching conditions given by Fleischer \& Price (1964) were generally applicable to the present minerals. The etching was only slightly adjusted to leave the majority of the pits with a sharply pointed bottom (see Figs. 4 and 5). $48 \% \mathrm{HF}$ was used as the etchant throughout. Details are given in Table 1.

A brief etch generally produced slender, cylindrical or conical pits. Prolonged etching resulted in an increased number of flat-bottomed pits. This flattening occurred when the pits had reached a length of $10-20 \mu$ in all samples. Most of the pits studied in this work have a welldefined, wide »entrance» with a slender tail (see Figs. 1-5). Generally they permit a proper identification as fission tracks. In the amphibole samples, some dislocations were observed, but they were clearly distinguishable due to their great length, curvature and localization to the $\{110\}$ planes.

At high magnifications, ill-defined etch pits are often displayed that tend to make fission

TABLE 1

Etching conditions with $48 \%$ hydrofluoric acid

\begin{tabular}{c|c|c|c}
\hline Sample & Time & Temp ${ }^{\circ} \mathrm{C}$ & $\begin{array}{c}\text { Crystal } \\
\text { plane }\end{array}$ \\
\hline $\begin{array}{c}\text { Hornblende, } \\
\text { RM 07249 ... }\end{array}$ & $1.5 \mathrm{~min}$ & 53 & $\{110\}$ \\
$\begin{array}{c}\text { Biotite, } \\
\text { RM 620569 .. }\end{array}$ & $30 \mathrm{sec}$ & 20 & $\{0001\}$ \\
$\begin{array}{c}\text { Phlogopite, RM } \\
\text { 640448-640451 }\end{array}$ & $2 \mathrm{~min}$ & 20 & $\{0001\}$
\end{tabular}




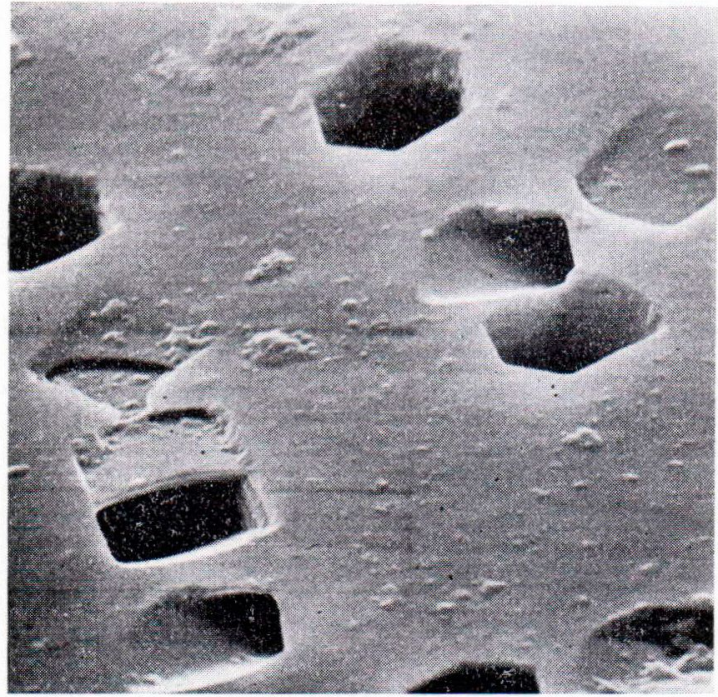

Fig. 1. Scanning electron micrograph of spontaneous fission tracks in hornblende RM 07249 on a $\{110\}$ cleavage plane. Note the different directions of the tracks. $6500 \mathrm{X}$.

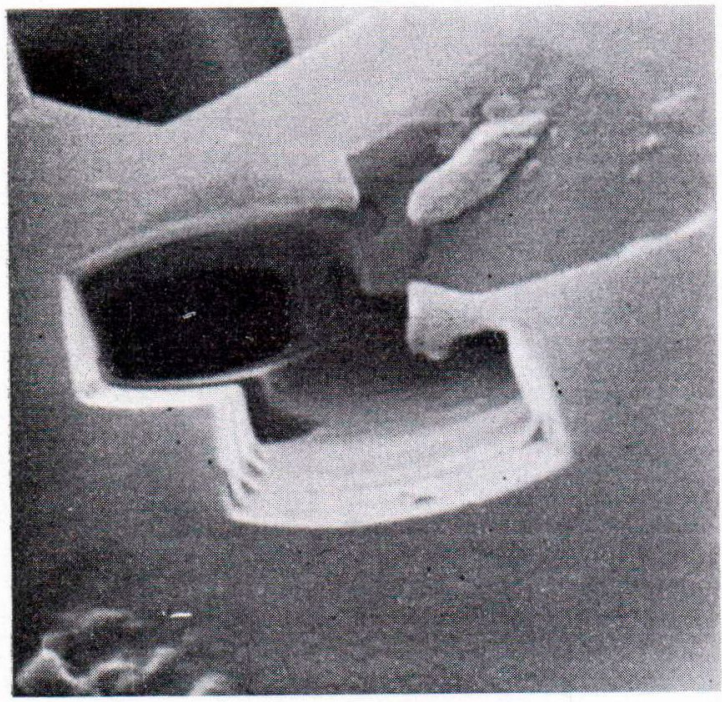

Fig. 2. Scanning electron micrograph of spontaneous fission tracks in hornblende RM 07249 on a $\{110\}$ cleavage plane. Note a stepwise dissolution along the tracks. $12000 \mathrm{X}$.

track identification cumbersome. A range of transitional types can be observed between welldeveloped fission tracks and nonidentificable pits (Figs. 3 and 4)). Since these observations apply

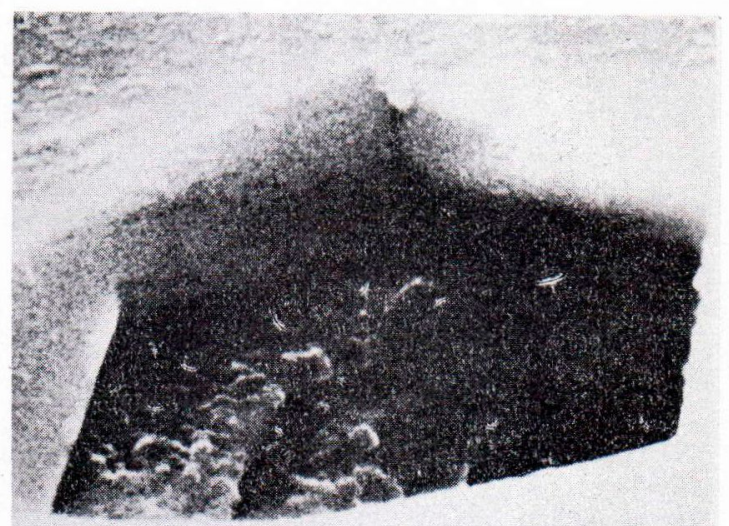

Fig. 3. Scanning electron micrograph of spontaneous fission track in biotite on the $\{0001\}$ plane. Note the hexagonal symmetry and the stepwise dissolution. $24000 \mathrm{X}$.

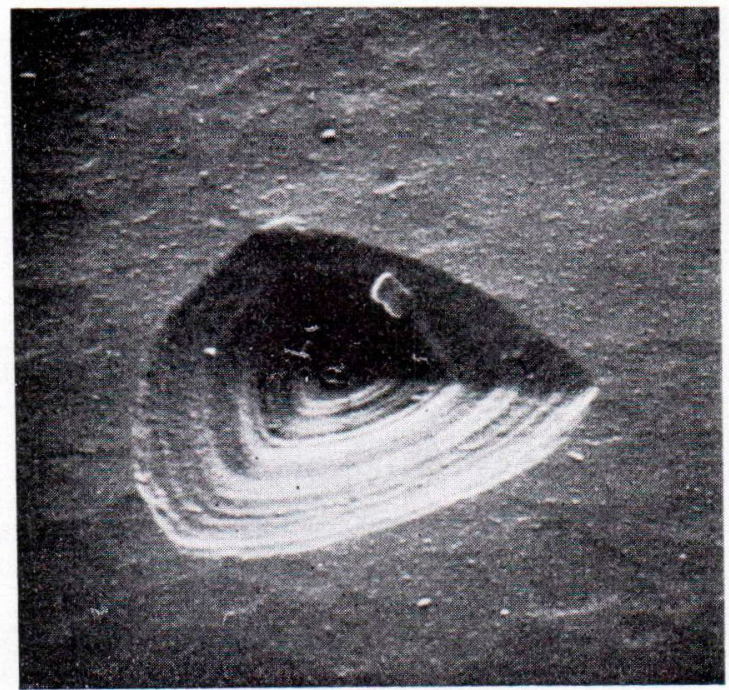

Fig. 4. Scanning electron micrograph of spontaneous fission track in biotite on the $\{0001\}$ plane. Trigonal symmetry often displayed at the bottom of etch pits of the type shown in Fig. 3. This fission apparently has occurred above the surface studied. The pit shown here represents only the end of a fission track. $9500 \mathrm{X}$.

equally well to irradiated and unirradiated specimens it has been concluded that essentially all etch pits must indicate fission tracks.

After the first etch, the sections were cleaned 


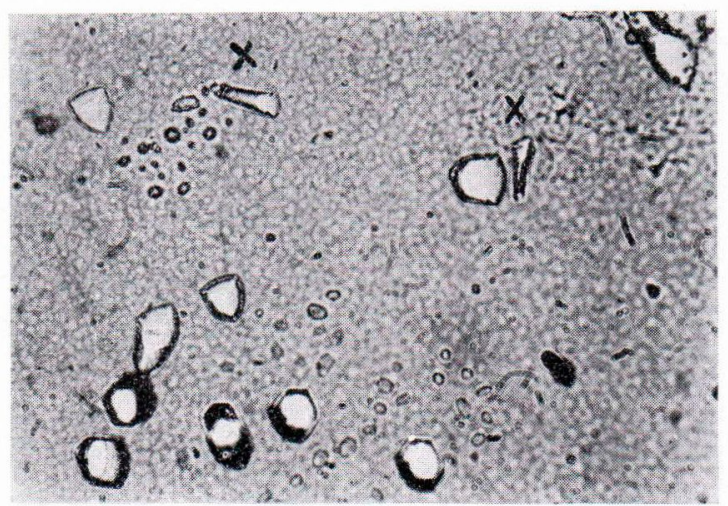

Fig. 5. Biotite in transmitted light, $890 \mathrm{X}$. The effect of double etching technique is clearly shown. Large etch pits show the site of spontaneous fissions, two small etch pits $(x)$ the induced fissions. The spontaneous tracks have been etched twice, the induced only once.

in an ultrasonic bath, dried with acetone in a dust free atmosphere and wrapped in a protective plastic foil (»Parafilm» made by the American Can Company) before they were irradiated. No signs of surface contamination like the track »sunbursts» described by Price \& Walker (1963 b) were found when the surfaces were protected in this way. The second etch was performed after the irradiation in a similar manner to the first etch.

\section{Irradiation}

The sections were irradiated with thermal neutrons in the R 1 reactor of the Atomic Energy Company in Stockholm. This reactor had a very stable and homogeneous neutron flux as can be seen from the error given below. The neutron flow varied between $(4.58-5.14 \pm 0.11) \times 10^{11}$ $\mathrm{n} / \mathrm{cm}^{2} \times \mathrm{sec}$ and the irradiation time was, with one exception, 5 hours. The fragments were stored in small containers each of which also contained a $1 \mathrm{~mm} \mathrm{Co-Al} \mathrm{wire} \mathrm{with} 0.51 \%$ Co from which the thermal neutron dose was determined by the Atomic Energy Company. The factor between the $2 \pi$ and $4 \pi$ geometries has been found to be 0.74 in the studied horn- blende. For the biotite and phlogopite samples a factor of 0.57 determined on muscovite by Reimer et al., 1970, has been used.

\section{Counting}

The fission track counts were performed with a Zeiss Standard Universal M microscope equipped with a $40 \times$ objective, a $12.5 \times$ eyepiece and the »Optovar» at $1.25 \times$. This microscope can be shifted between transmitted and reflected light instantaneously which was found very helpful for the identification of the tracks. In the eyepiece a quadratic grid covering 0.0256 square millimetres at this magnification was inserted. The tracks were registered on push-button counters. Thus, the counting person could register the tracks without taking his eye from the eyepiece grid which could have led to counting mistakes. The track homogeneity after irradiation and second etching was always studied by a preliminary counting and statistically evaluated in order to discard the samples with too wide a range of track densities and thus not suitable for dating. Many samples in fact showed obvious evidence of inhomogeneous track distribution.

The smallest counted area (the unit-area) embraced 0.23 square millimetres (i.e. nine eyepiece grid fields). Between 50 and 100 unit areas were counted on each sample and the total counted area covered ten to twenty square millimetres.

As mentioned in the preceding chapter, the double etching technique (Bigazzi 1967, Berzina and Demidova 1966) was applied. The counting was generally performed after the second etch and both kinds of tracks registered simultaneously. The spontaneous and induced tracks were usually dissimilar enough to permit this method (Figure 5). In some cases however, this method was abandoned since the tracks had grown too alike and the spontaneous tracks were counted before the second etch. 
TABLE 2

$\mathrm{K}-\mathrm{Ar}$ ages of fission track dated samples

\begin{tabular}{l|r|r|r|r}
\hline & $\begin{array}{c}\mathrm{K} \\
\% \mathrm{Wt}\end{array}$ & $\begin{array}{c}\mathrm{rad} \mathrm{Ar}^{40} \\
\mathrm{moles} / \mathrm{gm}\end{array}$ & $\begin{array}{c}\mathrm{Ar}^{40} \mathrm{rad} \\
\%\end{array}$ & $\begin{array}{c}\text { Age } \\
\text { million } \\
\text { years }\end{array}$ \\
\hline $\begin{array}{l}\text { Hornblende } \\
\text { RM 07249 ..... }\end{array}$ & 0.46 & $0.263 \cdot 10^{-8}$ & 90.5 & 1875 \\
$\begin{array}{l}\text { Biotite RM 620569 } \\
\text { Phlogopite RM }\end{array}$ & 7.46 & $1.697 \cdot 10^{-8}$ & 92.3 & 975 \\
$\quad$ 640448 640451 .. & 7.45 & $0.855 \cdot 10^{-8}$ & 91.3 & 555
\end{tabular}

$\lambda_{c}=0.585 \cdot 10^{-10} \mathrm{yr}^{-1}$

$\lambda_{\beta}=4.72 \cdot 10^{-10} \mathrm{yr}^{-1}$

$\mathrm{K}^{40}=1.19 \cdot 10^{-2}$ atom per cent

\section{$K-A r$ dating}

The $\mathrm{K}$-Ar dating has been done at the Geochronology Laboratory in Stockholm. Potassium was determined in duplicate as total $\mathrm{K}$ using a Zeiss PMQIIFA2 flame photometer briefly following a method by Cooper (1963) which was modified by a buffering technique according to Schuhkneckt and Schinkel (1963). Argon was measured by isotope dilution using $\mathrm{Ar}^{38}$ as tracer. The argon extraction was made in a bakeable glass high-vacuum fusion system linked to an AEI MS 10 mass spectrometer. The results of the $\mathrm{K}$-Ar dating are given in Table 2 .

\section{Description of samples}

Among fifteen preliminary investigated mica and amphibole samples from various geological environments, only three were found to fulfill the requirements on ease of preparation and homogeneity of track distribution, stated above. The location of the samples is shown in Fig. 6.

RM 07249 Hornblende, Kung Oscar shaft, Malmberget, Norrbotten County

This sample is a $15 \times 4 \times 3 \mathrm{~cm}$ :s large euhedral crystal with perfect $\{110\}$ prism faces. It is black with a greenish tint and exhibits a very good

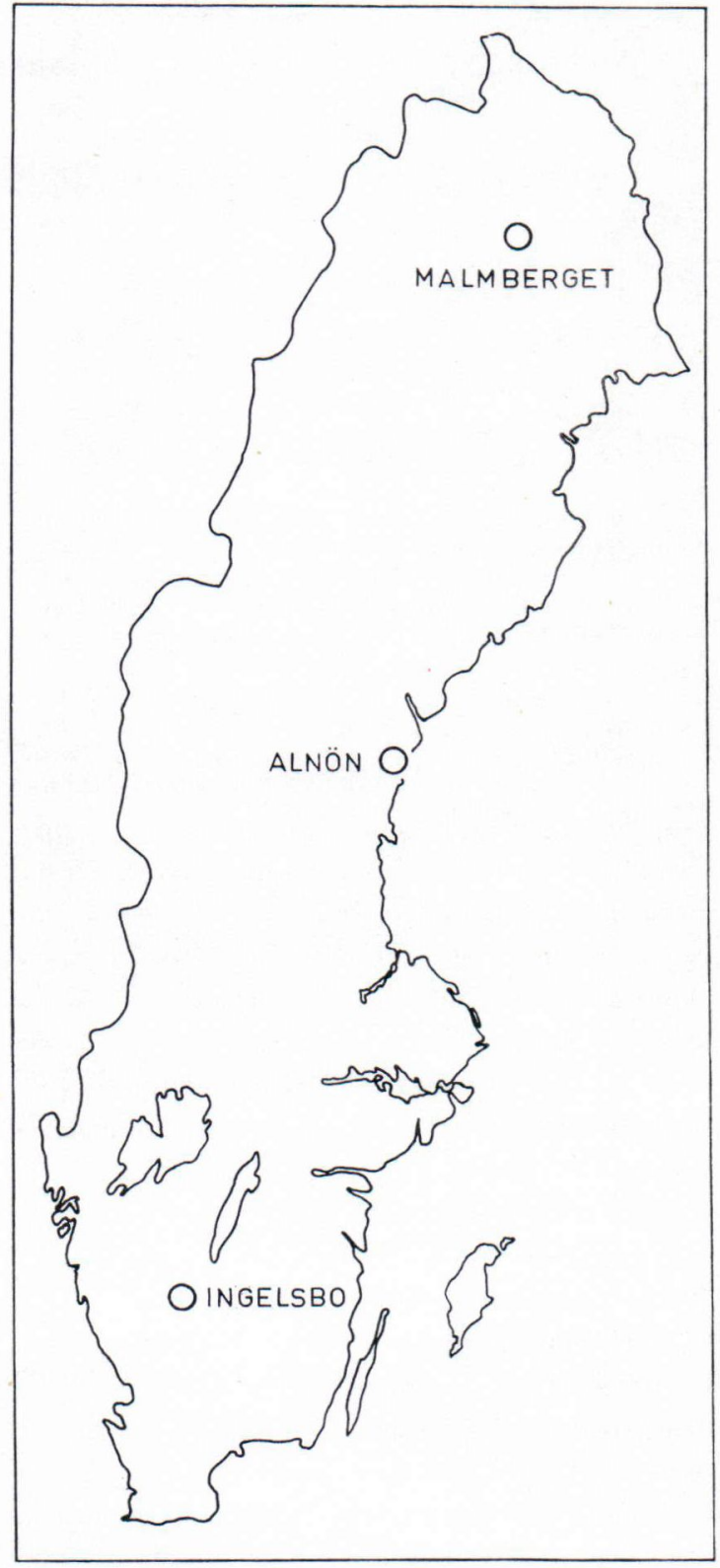

Fig. 6. Map showing the location of the investigated samples.

$\{110\}$ cleavage. The specimen is quite homogeneous throughout. A few fractures, parallel to the $c$-axis, occur. They are sometimes associated with dislocations in the $\{110\}$ plane. 
RM 620569 Biotite, Ingelsbo, Hestra parish,

Västergötland County

This biotite collected in a pegmatite quarry is about $10 \times 20 \times 1 \mathrm{~cm}$ :s in size, black in colour and has an excellent basal cleavage which made the preparation of translucent foils of uniform thickness very easy. No fractures were observed and the fission tracks show a homogeneous density. However, some evidence indicating uranium migration in this sample will be discussed below (p. 42).

\section{RM 640448-640451 Pblogopite in alnöite breccia, boulder in road-cut at Hovid, Västernorrland County}

This phlogopite forms reddish, euhedral crys tals about one centimetre in size in a greenish matrix of an alnöite breccia containing bedrock fragments. The mica has an acceptable basal cleavage and a relatively uniform track distribution. A few cracks occur and clusters of induced fission tracks are sometimes found here.

\section{Results}

The results of the fission track studies are given in Table 3. The detailed discussion of every sample is given below.

\section{RM 07249 Hornblende, Malmberget}

Two cleavage fragments, 1 and 2, from the same crystal were studied. In these fragments, spontaneous and induced fission tracks were too similar to permit simultaneous counting. The spontaneous tracks were therefore counted separately before the second etch. The track distribution was very homogeneous and probably there exist areas with homogeneous track distribution that are larger than the sections studied here.

A comparison of the two fragments, however, shows that they differ markedly in uranium content. If the appropriate $\varrho_{\mathrm{i}}$ and $\mathrm{n}$ values (Table 3 ) are substituted in Eq. (3) it is found that the uranium content of fragment 2 is approx. 3 times higher than in fragment 1 . The spontaneous track densities $\varrho_{\mathrm{s} 2}$ and $\varrho_{\mathrm{s} 1}$ (index numbers 2 and 1 refer to the fragment numbers) are of similar magnitude. The calculated ages of fragments 1 and 2 are $1255 \mathrm{~m} . \mathrm{y}$. and $450 \mathrm{~m}$.y. respectively.

The highly different ages may be explained in the following way. The distribution of induced tracks in fragment 1 is somewhat irregular, with diffuse clusters of tracks and a slight enrichment of tracks along small fissures. Furthermore, it is probable that an annealing of the hornblende crystal would cause a uniform decrease in the number of the spontaneous tracks. This is also indicated by the $\varrho_{s}$ values. Based on these ob-

TABLE 3

Fission track data.

\begin{tabular}{|c|c|c|c|c|c|c|}
\hline Sample & $\begin{array}{c}\text { Counted area } \\
\mathrm{mm}^{2}\end{array}$ & $\underset{\text { tracks } / \mathrm{mm}^{2}}{\varrho_{\mathrm{s}}}$ & $\begin{array}{c}o_{\mathrm{i}} \\
\text { tracks } / \mathrm{mm}^{2}\end{array}$ & $\underset{n}{n} \underset{\text { neutr. } / \mathrm{cm}^{2} \mathrm{sec}}{ }$ & $\begin{array}{l}\text { irradiation time } \\
\text { min }\end{array}$ & age in m.y. \\
\hline \multicolumn{7}{|l|}{ Hornblende 1} \\
\hline RM 07249 .. & 20.48 & 91.7 & 20.41 & $4.70 \times 10^{11}$ & 295 & 1255 \\
\hline \multicolumn{7}{|l|}{ Hornblende 2} \\
\hline RM $07249 \ldots \ldots$ & 23.04 & 90.10 & 60.63 & $4.70 \times 10^{11}$ & 300 & 450 \\
\hline Biotite 1 RM 620569 & 23.04 & 147.44 & 113.67 & $4.67 \times 10^{11}$ & 300 & 305 \\
\hline Biotite 2 RM 620569 & 23.04 & 199.09 & 88.68 & $4.67 \times 10^{11}$ & 300 & 520 \\
\hline Biotite 3 RM 620569 & 11.52 & 159.72 & 104.51 & 4. $66 \times 10^{11}$ & 300 & 355 \\
\hline Biotite 4 RM 620569 & 23.04 & 146.97 & 84.64 & $4.71 \times 10^{11}$ & 300 & 410 \\
\hline \multicolumn{7}{|l|}{ Phlogopite 1 RM } \\
\hline $640448-640451 \ldots$ & 17.28 & 24.54 & 24.83 & $4.58 \times 10^{11}$ & 300 & 230 \\
\hline $\begin{array}{l}\text { Phlogopite } 2 \text { RM } \\
640448-640451\end{array}$ & 17.28 & 20.60 & 19.96 & $4.58 \times 10^{11}$ & 300 & 240 \\
\hline
\end{tabular}

$6 \quad 14993-71$ 


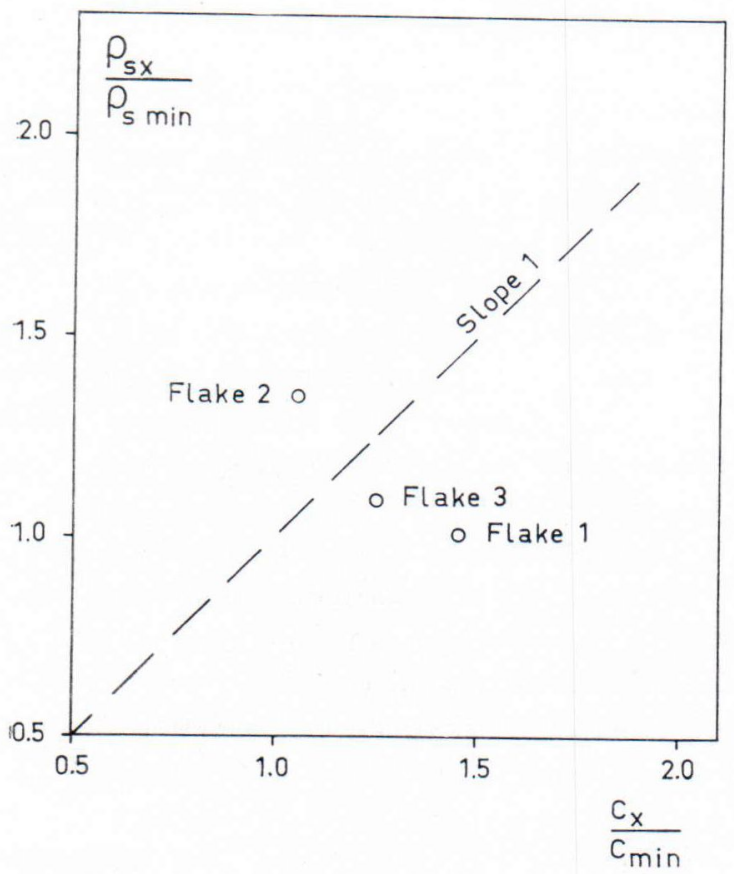

Fig. 7. Diagram showing the ratio of relative spontaneous fission track densities $\left(\left(\varrho_{\mathrm{x}} / \varrho_{\mathrm{s}_{\text {min }}}\right)\right.$ versus the relative uranium content $\mathrm{C}_{\mathrm{x}} / \mathrm{C}_{\min }$ of the biotite samples. RM 620569.

servations, the calculated ages can be explained by a combined action of a thermal track fading and a recent uranium loss. The net result would be a high age for fragment 1 , which has suffered both uranium loss and a fading of spontaneous tracks, and a low age for fragment 2 which has only suffered track fading.

\section{RM 620569, Biotite, Ingelsbo}

Four different flakes (1-4) from this large biotite crystal were irradiated simultaneously and studied in both reflected and transmitted light. The type of illumination apparently does not affect the results as highest and lowest ages were both found from track counts in transmitted light.

All flakes display a homogenous track distribution within the unit areas but a marked difference between the unit areas within the same fragment. The spontaneous fission track density also shows no correlation with the $U$ content of the different flakes. Fragment 4 has both the lowest relative uranium concentration $\mathrm{C}_{\min }$ (according to Eq. (3)) and the minimum $\varrho_{s_{\min }}$ of the investigated biotite flakes. The $\varrho_{\mathrm{s}}$ and C values of the samples 1,2 and 3 therefore have been expressed in terms of ratios of the values of sample 4 and plotted in a diagram (Fig. 7) showing the ratio of relative spontaneous fission track densities versus the relative uranium content of the samples. If no uranium migration has occurred the $\varrho_{\mathrm{s}_{\mathrm{x}}} / \varrho_{\mathrm{s}_{\min }}$ ratio should be strictly corlated with the $\mathrm{C}_{\mathrm{x}} / \mathrm{C}_{\mathrm{rin}}$ ratio and the points should plot on a line with slope 1 according to Eq. (1), which for constant t gives $\varrho_{\mathrm{s}}=$ konst $C_{\mathrm{t}}$. The three biotite points, however, scatter at a right angle to this line, which strongly suggests uranium movements at some time.

Fig. 8 shows $\varrho_{\mathrm{s}}, \varrho_{\mathrm{i}}, \varrho_{\mathrm{s}}+\varrho_{\mathrm{i}}$ along a $12 \mathrm{~mm}: \mathrm{s}$ long profile in flake no. 1 . In spite of considerable variations along the profile, it appears that $\varrho_{s}$ and $\varrho_{\mathrm{i}}$ are inversely proportional to each other, giving a roughly constant $\varrho_{\mathrm{s}}+\varrho_{\mathrm{i}}$ value. However, along a portion of the profile about $2 \mathrm{~mm}$ long not a single spontaneous fission track is found, but the induced fission track density is raised to about 5 tracks/grid field. This inhomogeneous distribution of $\varrho_{s}$ and the absence of proportionality between $\varrho_{\mathrm{s}}$ and $\varrho_{\mathrm{i}}$ points (1.) to an original inhomogeneity in the distribution of uranium and (2.) to a substantial uranium migration in the mineral. Assuming the existence of a single spontaneous fission track within this area, it is possible according to eq. (5) to calculate that the uranium redistribution took place 40 m.y. ago. However, no spontaneous tracks are visible in this area and thus the redistribution of uranium has occurred at a later time.

The features described above further show that the uranium migration is at least partly internal in the large crystal. If the biotite points in Fig. 7 had plotted distinctly on either side of the line, this would have been specific evidence 


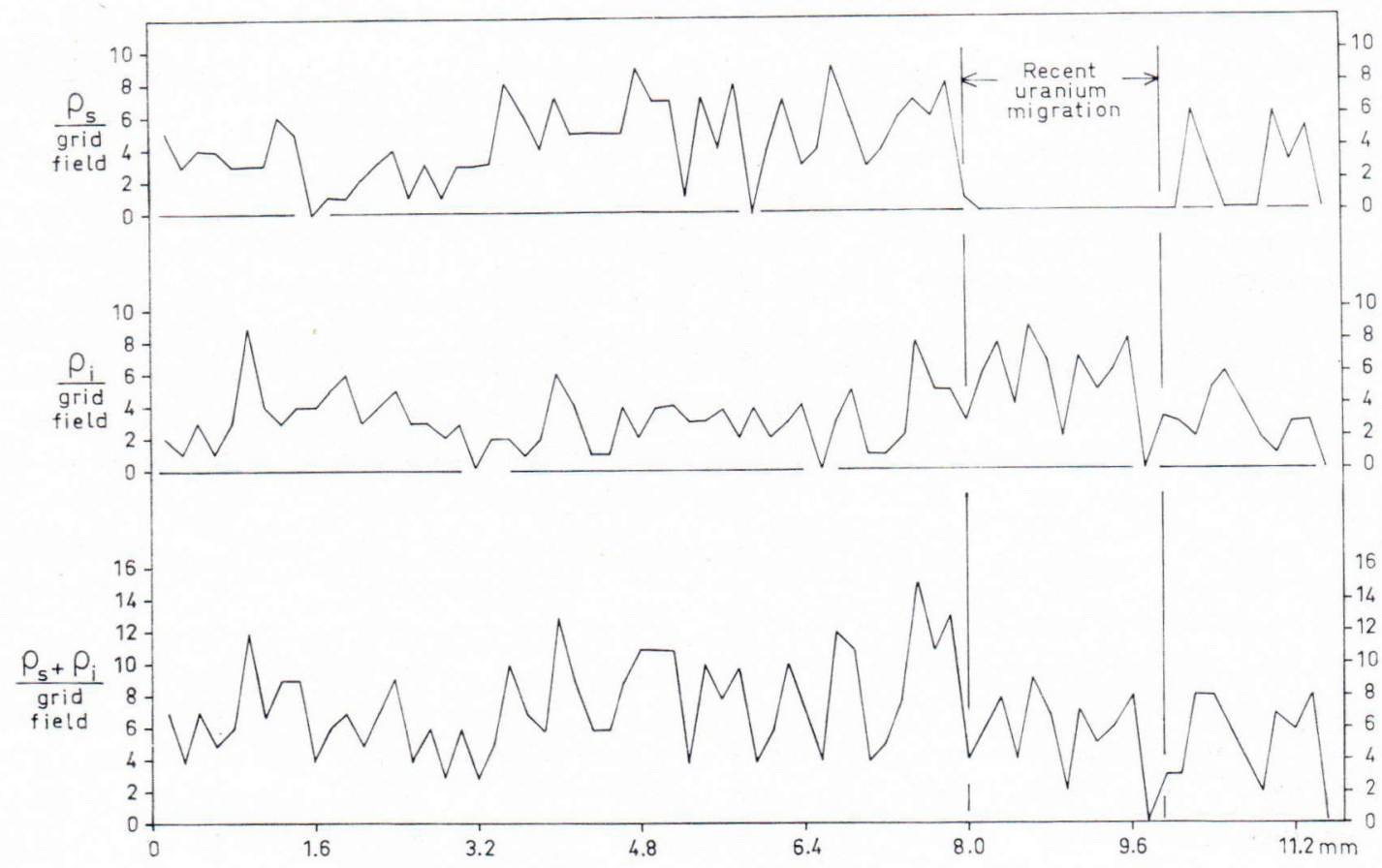

Fig. 8. Fission track densities $\varrho_{\mathrm{s}}, \varrho_{\mathrm{i}}$ and $\varrho_{\mathrm{s}}+\varrho_{\mathrm{i}}$ along a $12 \mathrm{~mm}: \mathrm{s}$ long profile in biotite. RM 620569.

for enrichment or depletion of uranium. Thus a fission track count of a sufficiently large part of the crystal should theoretically enable one to eliminate these effects, but this is a very time-consuming task which has not been undertaken.

On the normal-sized flakes the following ages were calculated: flake n:o 1: 305 m.y., flake n:o 2: 520 m.y., flake n:o 3: 305 m.y. and flake n:o 4: $410 \mathrm{~m} . \mathrm{y}$.

\section{RM 640448-640451, Pblogopite, Alnön}

Two cleavage fragments from different phlogopite crystals in the same hand specimen ( 1 and 2) were irradiated simultaneously and studied in reflected light. Translucent sections were easily prepared, but the tracks were difficult to recognize in transmitted light because of frequent shadows from the interior of the flakes. The sections showed relatively homogeneous track distributions, but clusters of induced fission tracks were often found along fracture lines, indicating that some $U$ migration must have taken place in the crystals. Such areas were avoided in the counting. The migration is, however, of limited magnitude since $\varrho_{\mathrm{s}_{1}} / \varrho_{\mathrm{s}_{2}}=1.19$ and $\mathrm{C}_{1} / \mathrm{C}_{2}=1.24$ (Eq. 3) of the two crystals are of similar magnitudes. The ages of the two crystals are comparable: the age of fragment 1 is $230 \mathrm{~m} . \mathrm{y}$. and of fragment $2240 \mathrm{~m} . \mathrm{y}$.

\section{Discussion}

Experience has shown that the fission track ages of minerals tend to be lower than their isotopic ages, whereas the fission track ages for natural glasses more often agree well with ages determined by $\mathrm{K}$-Ar method (Fleischer and Price 1964, Wagner 1966, Miller 1968). The lowering of ages in minerals may be caused by a temperature dependent fading of tracks or a 
change in uranium concentration with time (Fleischer and Price 1964). Annealing experiments carried out on minerals and glasses (Fleischer and Price 1964, Fleischer et al. 1964, Maurette et al. 1964, and Fleischer et al. 1965) as a function of pressure have shown that minerals can be arranged in an order of decreasing track fading susceptibility at elevated temperatures. Annealing in muscovite, for example, takes place more easily than in hornblende. The tracks have faded completely at $550^{\circ}$ and $620^{\circ}$, respectively. Hydrostatic pressures down to about $10 \mathrm{~km}$ of rock do not accelerate the track annealing in these minerals.

In a detailed study, Fleischer et al. (1964) concluded that tracks in mica "would be stable over the entire age of the earth at approximately $145^{\circ} \mathrm{C}$ but would anneal out in only a million years at about $200^{\circ}$ C.» Fleischer and Price (1964) predicted that fission tracks in tektites at room temperature $\left(23^{\circ} \mathrm{C}\right)$ would last $10^{21}$ years and would fade in $100 \mathrm{~m} . \mathrm{y}$. at $170^{\circ} \mathrm{C}$ only if maintained at this temperature for the entire time. Recent annealing experiments on tektites extrapolated to geologic times (Storzer 1970), however, indicate that $25 \%$ of spontaneous tracks would be retained under the last mentioned conditions and further that a 100 m.y. old tektite kept at $25^{\circ} \mathrm{C}$ during its entire lifetime would retain only $65 \%$ of its tracks. If this latter extrapolation is correct and can be extended to minerals, it would imply that a continuous, slow self-healing of the damaged lattice takes place. Wagner (1969) pointed out on the basis of similar heating experiments that a retention temperature merely is a temperature range within which the stability of the tracks is subject to strong transformations. Furthermore, he concluded that this temperature range is dependent on the cooling time. Another indication of a spontaneous disappearance of fossil tracks at low temperatures during long geological times has been given by Bigazzi (1967) who showed that a relation between track length and geologic age exists in muscovite.
The preceeding discussion shows that there is a possibility that very old geological samples may, even without suffering a thermal event or chemical redistribution of uranium, show too low fission track ages. A consequence of the work of Storzer (1970) and Wagner $(1966,1969)$ is that the geologically determined decay constant (6.9 . $\left.10^{-17} \mathrm{yr}^{-1}\right)$ for the spontaneous fission of $\mathrm{U}^{238}$ (Fleischer and Price 1964) may be too low. In the present study the decay constant $8.42 \cdot 10^{-17}$ $\mathrm{yr}^{-1}$ (Spadaveccia and Hahn, 1967) has been used. The minerals described here have also been the subject of $\mathrm{K}$ - Ar dating at the Geochronology Laboratory in Stockholm (Table 2). The K-Ar age of the hornblende is 1875 m.y. A thermal event, caused by the intrusion of granites in the close vicinity, has affected the hornblendebearing skarn 1565 m.y. ago (Welin et al. 1971). The hornblende age is therefore surprisingly high. This may be due either to a high argon retentivity by the hornblende and/or to a rather significant amount of inherited argon. The pegmatite carrying the investigated biotite was formed according to $\mathrm{U}-\mathrm{Pb}$ dating $935 \mathrm{~m}$.y. ago (Welin and Blomqvist, 1964). The K-Ar age of the biotite, 975 m.y., agrees fairly well with this age and virtually all argon produced by radioactive decay is retained. The $\mathrm{K}-\mathrm{Ar}$ age of the phlogopite is $555 \mathrm{~m} . \mathrm{y}$. This age agrees well with a previous estimation of the age of pyrochlore in soevite (v. Eckermann and Wickman, 1956) and with the age of similar carbonatitic rocks in the Fen area in Norway (Faul et al., 1959).

A comparison with the $\mathrm{K}-\mathrm{Ar}$ ages shows that the fission track ages are far too low. The reason for this may be a fading of tracks at elevated temperatures. The retention of fission tracks is lower than the Ar retention at the same temperature and annealing below the treshold for Ar diffusion would therefore retain $\mathrm{K}$-Ar ages but affect the fission track ages. The cooling time and uplift of the orogenic zone in which the hornblende and biotite samples have been situated may have lasted some 100 m.y. This, 
however, does not explain the low fission track ages. Another, although more remote, explanation is that the Caledonian orogeny, with a maximum intensity at about $420 \mathrm{~m}$.y., also has affected the eastern foreland. The hornblende sample from Malmberget in particular has been situated only $100 \mathrm{~km}$ east of the Caledonian orogenic zone. In southern Sweden basaltic magma has erupted at $282 \pm 5 \mathrm{~m}$.y. (Priem et al., 1968). Thick layers of dolerite are found $80 \mathrm{~km}$ north of the biotite locality at Ingelsbo.

One further cause to low fission track ages may be found in a uranium loss. As described in the preceeding chapter, inhomogeneous track distribution was often found in this work, especially in micas. These minerals frequently displayed highly different track densities on different $\{0001\}$ cleavage surfaces which indicates a basal stratification of the uranium content of the crystal. In addition, on the same $\{0001\}$-plane recent uranium migrations have occurred both in the biotite and the phlogopite.

In evaluating the potential of fission track dating for Precambrian rock forming minerals, the above results are not very encouraging.
Furthermore, these three minerals have been selected from a collection of fifteen minerals which were estimated to be suitable for dating. Considerable difficulties are therefore to be expected in finding appropriate minerals. The geological evolution in the Precambrian of Sweden has been very complex, involving at least two major orogenic periods. It seems clear that fission track ages reflect only the last event in the thermal history. The conclusion must be drawn that fission track dating of silicate minerals of the investigated type from the Swedish Precambrian cannot be carried out successfully. The technique, however, may supply information about the last thermal event, although the work necessary for such a study is considerable.

Acknowledgement - The authors wish to express their sincere gratitude to Dr. P. H. Lundegårdh for his generosity 'n permitting the SGU-employee (I. L.) to participate in this project. For his interest and help in taking the scanning electron micrographs the authors are indebted to Dr. J. Malmqvist. The K-Ar dating has been carried out at the Geochronology Laboratory in Stockholm by $\mathrm{Mr} \mathrm{K}$. Christiansson and Mr J.-O. Everts,on. To all these persons the authors offer their sincere thanks.

\section{LITERATURE}

Berziná, I. G. and Demidova, P. G., 1966: Determining the ages of minerals by means of the tracks of fission fragments from uranium nuclei. Atomnaya Energiya, Vol. 21, p. 304.

BigazzI, G., 1967: Length of fission tracks and age of muscovite samples. Earth Planet. Sci. Lett. Vol. 3, p. 434.

Cooper, J. A., 1963: The flame photometric determination of potassium in geological materials used for potassium-argon dating. Geochem. et Cosmochim. Acta, Vol. 27, p. 525.

v. Eckermann, H. and Wickman, F. E., 1956: A preliminary determination of the maximum age of the Alnö rocks. Geol. Fören. Stockholm Förh. Vol. 78, p. 122.

Faul, H., Elmore, P. L. D. and Brannock, W. W., 1959: Age of the Fen carbonatite (Norway) and its relation to the intrusives of the Oslo region. Geochim. et Cosmochim. Vol. 7, p. 153.
Fleischer, R. L. and Price, P. B., 1964: Techniques for geological dating of minerals by chemical etching of fission fragment tracks. Geochim. et Cosmochim. Acta. Vol. 28, p. 1705.

- 1964: Glass dating by fission fragment tracks. J. Geophys. Res. Vol. 69, p. 331.

- Symes, E. M. and Miller, D. S., 1964: Fission-track ages and track-annealing behaviour of some micas. Science, Vol. 143, p. 349.

- and WALker, R. M., 1965: Effects of temperature, pressure and ionization of the formation and stability of fission tracks in minerals and glasses. J. Geophys. Res., Vol. 70, p. 1497.

Maurette, M., Pellas, P. and Walker, R. M., 1964: Étude des traces de fission fossiles dans le mica. Bull. Soc. franc. Minér. Crist. Vol. LXXXVII, p. 6.

Miller, D. S., 1968: Fission track ages on 250 and 2500 m.y. micas. Earth Planet. Science Lett., Vol. 4, p. 379. 
Price, P. B. and Walker, R. M., 1962 a: Electron microscope observation of etched tracks from spallation recoils in mica. Phys. Rev. Lett. Vol. 8, p. 217.

- $1962 \mathrm{~b}$ : Chemical etching of charged-particle tracks in solids. J. Appl. Phys., Vol. 33, p. 3407.

- 1963 a: A simple method of measuring low uranium concentrations in natural crystals. Appl. Phys. Letters. Vol. 2, p. 23.

- $1963 \mathrm{~b}$ : Fossil tracks of charged particles in mica and the age of minerals. J. Geophys. Res., Vol. 68, p. 4847.

Priem, H. N. A., Mulder, F. G., Boelrijk, N. A. I. M., Hebeda, E. H., Verschure, R. H. and Verdurmen, E. A. T. H., 1968: Geochronological and paleomagnetic reconnaissance survey in parts of central and southern Sweden. Phys. Earth Planet. Interiors Vol. 1, p. 373.

Reimer, G. M., Storzer, D., and Wagner, G. A., 1970: Geometry factor in fission track counting. Earth and planetary science letters Vol, 9, p. 401.

Schuhknechr, W. and Schinkel, H., 1963: Beitrag zur Beseitigung der Anregungsbeeinflussigung bei flammenspektralanalytischen Untersuchungen. Z. analyt. Chem., Bd 194, p. 161.
Spadaveccia, A. and Hahn, B., 1963: Die Rotationskammer und einige Anwendungen. Helv. Phys. Acta 40, p. 1063.

Storzer, D., 1970: Fission track dating of volcanic glasses and the thermal history of rocks. Earth Planet. Science Lett. Vol. 8, p. 55.

WAgNer, G. A., 1966: Altersbestimmungen an Tektiten und anderen natürlichen Gläser mittels Spuren der spontanen Spaltung des Uran ${ }^{238}$ (»fission-track»)Methode). Z. Naturforschung. Bd 21, p. 733.

- 1969: Spuren der spontanen Kernspaltung des ${ }^{238}$ Urans als Mittel zur Datierung von Apatiten und ein Beitrag zur Geochronologie der Odenwaldes. N. Jb. Miner. Abh. 110, p. 252.

Welin, E., and Blomevist, G., 1964: Age measurements on radioactive minerals from Sweden. Geol. Fören. Stockholm Förh. Vol. 86, p. 33.

Welin, E., Christiansson, K., and Nilsson, Ö., 1971: $\mathrm{Rb}-\mathrm{Sr}$ radiometric ages of extrusive and intrusive rocks in northern Sweden. I. Sveriges Geol. Undersökn. Ser. C. In print.

Manuscript received, May 5, 1971. 